\title{
Problematyka gospodarki finansowej jednostek samorządu terytorialnego w kontekście realizacji zadań publicznych
}

\section{Dilemmas of financial policy of local government units in a context of implementation of public tasks}

Streszczenie. Celem artykułu jest wskazanie wyzwań stojących przed jednostkami samorządu terytorialnego ${ }^{1}$ ze szczególnym uwzględnieniem problematyki gospodarki finansowej tych jednostek. W artykule poddano analizie przepisy prawa w zakresie polityki finansowej jednostek samorządu terytorialnego, oznaczono słabe i mocne strony obowiązujących rozwiązań. Dla zobrazowania zagadnienia gospodarki finansowej j.s.t. w kontekście zrównoważonego rozwoju opracowanie zawiera definicję pojęcia, zasady jej prowadzenia oraz analizę przepisów prawa krajowego i unijnego w tym zakresie. W artykule wykorzystano metodę dogmatyczno-prawną, która pozwoliła na określenie, jak prowadzona jest gospodarka finansowa w gminach, powiatach i województwach poprzez odniesienie się

$1 \quad$ Dalej: j.s.t. 
do przepisów prawa oraz zadań j.s.t. Podjęto próbę identyfikacji problemów gospodarki finansowej gmin, powiatów i województw. Zaproponowano rozwiązania, które mogłyby przyczynić się do zwiększenia efektywności zarządzania środkami publicznymi, a tym samym wspierania zrównoważonego rozwoju jednostek samorządowych. Doskonalenie gospodarki finansowej sektora samorządowego jest procesem złożonym, który wymaga zaangażowania wszystkich zainteresowanych osiągnięciem przez społeczności lokalne standardów jakościowych, które przyczynią się do zrównoważonego rozwoju.

Słowa kluczowe: jednostki samorządu terytorialnego; stabilność finansowa; gospodarka finansowa; zasada adekwatności; zarządzanie środkami publicznymi.

Abstract. This article aims at identification of the challenges which local government units are facing. Particular emphasis will be put on issues related to the financial management of these units. The article describes problems of performing tasks at a level of a community, county and self-government province. The text presents a range of own and delegated duties of the previously-mentioned units. It also refers to an organizational - legal form of performed tasks. The article puts a special emphasis on dilemmas of financial economy of local government sector. The aim of this paper is to study a transformation of a present financial policy of local government units, to point out weaknesses and strengths of current solutions. A definition of a balanced development is given to identify measures of implementation of this development, and to refer to problems of financial policy which require a joint engagement in solving them. The article also estimates a real chance for a change of the local government sector financial structure (regulations and functioning rules), as well as for an implementation of new decision-making methods that would improve the effectiveness of public finance management.

Keywords: local government units; financial stability; financial policy; the principle of adequacy; public money management.

\section{Wprowadzenie}

Problematyka gospodarki finansowej jednostek samorządu terytorialnego jest związana z procesem stałego gromadzenia środków oraz dokonywania wydatków przez gminy, powiaty i województwa. Funkcjonowanie 
tych jednostek oparte jest na rozliczeniach finansowych, które mają formę procedur, w szerokim ujęciu rozumianych jako gospodarka finansowa. To także nieustanna działalność prowadzona w sferze operacji pieniężnych w sektorze samorządowym. Zagadnienie to nie może być analizowane statycznie, bowiem istotą gospodarki finansowej jest działanie wielopłaszczyznowe, wymagające dynamicznego postrzegania określonych zależności, z uwzględnieniem zmienności przepływów pieniężnych. Rozliczenia dokonywane przez j.s.t. dotyczą: pozyskiwania środków, wydatkowania ich w oparciu o rachunek opłacalności i dostępności źródeł finansowania, wypłacania wynagrodzeń w sektorze samorządowym, finansowania działalności jednostek sektora finansów publicznych.

Dla zobrazowania zagadnienia gospodarki finansowej j.s.t. w kontekście zrównoważonego rozwoju opracowanie zawiera definicję pojęcia, zasady jej prowadzenia oraz analizę przepisów prawa krajowego i unijnego w tym zakresie. Opracowanie przygotowane zostało w oparciu o przepisy Konstytucji Rzeczpospolitej Polskiej z dnia 2 kwietnia 1997 r. ${ }^{2}$, Europejską Kartę Samorządu Lokalnego ${ }^{3}$, ustawy regulujące funkcjonowanie gminy $^{4}$, powiatu ${ }^{5}$ i województwa ${ }^{6}$, ustawę o finansach publicznych ${ }^{7}$, ustawę o dochodach jednostek samorządu terytorialnego ${ }^{8}$, literaturę przedmiotu oraz orzecznictwo Trybunału Konstytucyjnego ${ }^{9}$. W artykule wykorzystano metodę dogmatyczno-prawną, która pozwoliła na określenie, jak prowadzona jest gospodarka finansowa w gminach, powiatach

2 Konstytucja Rzeczpospolitej Polskiej z dnia 2 kwietnia 1997 r., (Dz.U. z 1997 r. Nr 78, poz. 483 ze sprost.), dalej: Konstytucja RP.

3 Europejska Karta Samorządu Lokalnego, sporządzona w Strasburgu dnia 15 października 1985 r. (Dz.U. z 1994 r. Nr 124 poz. 607 ze sprost.), dalej: EKSL.

4 Ustawa z dnia 8 marca 1990 r. o samorządzie gminnym (tekst jedn. Dz.U. z 2019 poz. 506 ze zm.), dalej: u.s.g.

5 Ustawa z dnia 5 czerwca 1998 r. o samorządzie powiatowym (tekst jedn. Dz.U. 2019 r. poz. 511 ze zm.), dalej: u.s.p.

$6 \quad$ Ustawa z dnia 5 czerwca 1998 r. o samorządzie województwa (tekst jedn. Dz.U. 2019 r. poz. 512 ze zm.), dalej: u.s.w.

7 Ustawa z dnia 27 sierpnia 2009 r. o finansach publicznych (tekst jedn. Dz.U. z 2019 r. poz. 869 ze zm.), dalej: u.f.p.

8 Ustawa z dnia 13 listopada 2003 r. o dochodach jednostek samorządu terytorialnego (tekst jedn. Dz.U. z 2020 r. poz. 23 ze zm.), dalej: u.d.j.s.t.

9 Dalej: TK. 
i województwach poprzez odniesienie się do przepisów prawa oraz zadań j.s.t.

Kompetencje samorządu terytorialnego określone zostały w przepisach prawa. Podział na jednostki ma za zadanie zapewnić mieszkańcom gmin, powiatów i województw poczucie identyfikacji oraz daje możliwość sprawowania kontroli ${ }^{10}$, stanowi także podstawę dla prawidłowego funkcjonowania demokratycznego państwa prawa ${ }^{11}$.

\section{Pojęcie gospodarki finansowej jednostek samorządu terytorialnego}

Pojęcie gospodarki finansowej w znaczeniu szerokim to zespół czynności o charakterze faktycznym i prawnym, które są powiązane z pozyskiwaniem środków i wykorzystywaniem ich zgodnie z zadaniami, jakie realizuje dany podmiot. W zakresie podmiotowym pojęcie to obejmuje co do zasady jednostki organizacyjne, które na gruncie przepisów prawa finansowego zaliczane są do jednostek sektora finansów publicznych. Podmioty te nie mogą dysponować środkami finansowymi w sposób swobodny, nawet jeśli posiadają samodzielność w zakresie podejmowania decyzji o charakterze majątkowym i prawnym.

Zarządzanie gospodarką finansową j.s.t. należy analizować w ujęciu kompleksowym, które umożliwia powiązanie jej stanu w skali danej jednostki z krajową gospodarką finansową. Zarządzanie oznacza: kształtowanie i ustalanie założeń polityki finansowej jednostki, tworzenie prawa miejscowego w zakresie procesu realizacji zadań j.s.t. oraz gromadzenia dochodów niezbędnych do ich realizacji czy kierowania procesem planowania celów, metod i środków do wykonania zadań. Na poziomie samorządowym powinno mieć ono charakter wielopłaszczyznowy, czyli obejmować wyznaczanie i realizację założeń polityki finansowej j.s.t. (dochodowej i wydatkowej), jej koordynację, monitorowanie i weryfikowanie

10 E. Wojciechowski, Gospodarka samorzqdu terytorialnego, Warszawa 2012, s. 27.

11 H. Szczechowicz, Wykonywanie zadań publicznych w jednostkach samorzqdu terytorialnego, „Zeszyty Naukowe Państwowej Wyższej Szkoły Zawodowej we Włocławku. Zbliżenia Cywilizacyjne” 2015, nr 11, s. 256. 
wykorzystywania zasobów finansowych oraz mierzenie efektów podejmowanych działań. Zarządzający finansami j.s.t. powinni podejmować decyzje finansowe, odnosząc się do zmieniających się w sposób dynamiczny warunków działania i nowych potrzeb społeczności lokalnych ${ }^{12}$.

Istotą gospodarki finansowej jest nie tylko gromadzenie i wydatkowanie środków, ale także, a może przede wszystkim, wykonywanie zadań o charakterze krótko- i długoterminowym, ich analiza w celu podejmowania bardziej efektywnych decyzji i eliminowania występujących uchybień. Wymaga to uwzględnienia na poszczególnych etapach określonych czynności:

- o charakterze przygotowawczym dla operacji finansowych, które mają zostać podjęte przez podmioty. Działania te obejmują wszystkie etapy od prognozowania i planowania aż do podjęcia decyzji, która uwzględnia podstawowe zmienne w postaci potencjalnych korzyści dla społeczeństwa, czasu realizacji przedsięwzięcia oraz ryzyka;

- $\quad$ powiązanych z rzeczywistą realizacją operacji pieniężnych w zakresie przeprowadzania operacji bankowych na środkach publicznych, które mają wpływ na stan należności i zobowiązań;

- $\quad$ monitorujących przebieg dynamiki zjawisk finansowych oraz analizy uzyskanych danych, która pozwoli wyciągnąć wnioski na przyszłość.

Zakres czynności upodabnia funkcjonowanie gospodarki finansowej j.s.t. do działalności przedsiębiorstwa ${ }^{13}$. Racjonalne decyzje podejmowane w zakresie gospodarki finansowej na poziomie samorządu lokalnego umożliwiają realizowanie postulatów, na które wskazują członkowie lokalnych społeczności, co w efekcie przynosi skuteczne decyzji o sposobie wydatkowania środków publicznych. W celu zapewnienia racjonalności i skuteczności dysponowania środkami publicznymi kluczową rolę odgrywa poszukiwanie przez decydentów najkorzystniejszych rozwiązań oraz wykorzystanie środków pochodzących ze źródeł zewnętrznych, jeśli

12 M. Ofiarska, Zarzqdzanie gospodarkq finansowq j.s.t. i zwiq̨zana z tym organizacja urzędów j.s.t. [w:] C. Kosikowski, J.M. Salachna (red.), Finanse samorzq̨dowe, Warszawa 2012, s. 56.

13 Por. M. Dylewski , B. Filipiak, M. Gorzałczyńska-Koczkodaj, Podstawy analizy finansowej w jednostkach samorzqdu terytorialnego, Szczecin 2003, s. 131-143; I. Szyszko, J. Szczepański (red.), Finanse przedsiębiorstwa, Warszawa 2003, s. 19-30. 
taka możliwość istnieje, na przykład poprzez zawieranie umów o partnerstwo publiczno-prywatne.

\section{Ewolucja kształtowania się rozwiązań prawnych w zakresie dochodów jednostek samorządu terytorialnego}

Dla pełnego zobrazowania przemian klasyfikacji dochodów jednostek samorządu terytorialnego historycznie zasadnym jest rozpoczęcie od okresu po odzyskaniu niepodległości, czyli roku 1918. Od tego momentu analizować można początki tworzenia się nowoczesnego samorządu terytorialnego, który $\mathrm{w}$ założeniach miał być jednolity i samodzielny. W pierwszym okresie po odzyskaniu niepodległości głównym celem było ujednolicenie obowiązujących regulacji prawnych.

Istnienie samorządu terytorialnego, z uwzględnieniem jego dochodów, określone zostało w Konstytucji Marcowej. Dochody państwa i j.s.t. były autonomiczne. Jednostki samorządu terytorialnego wyposażone były we własne środki, ponadto zagwarantowano im źródła dochodów odrębne od źródeł dochodów państwa. Regulacje te należy uznać za fundament dla wprowadzenia zasady samodzielności publicznoprawnej j.s.t., w szczególności w zakresie podejmowania decyzji o przeznaczeniu środków przyznanych tym podmiotom w ustawach. Aktem prawnym, który w sposób kompleksowy normował w tamtym okresie zagadnienie dochodów j.s.t., była ustawa z dnia 11 sierpnia 1923 r. o tymczasowem uregulowaniu finansów komunalnych ${ }^{14}$. Określono w niej zarówno źródła dochodów j.s.t., jak i procedury stanowienia i poboru oraz organy nadzorcze.

Po kolejnej zmianie Konstytucji, która miała miejsce w 1935 r., rola samorządu terytorialnego w strukturze zarówno administracji publicznej, jak i całego państwa ukierunkowana została na wzmocnienie władzy wykonawczej, co nie wpłynęło jednak w istotny sposób na kształtowanie struktury dochodów j.s.t.

14 Tekst jedn. Dz.U. z 1936 r. Nr 62, poz. 454 ze zm. 
Wyodrębnienie w III Rzeczpospolitej samorządu terytorialnego realizującego kryteria decentralizacji państwa spowodowało konieczność wydzielenia przez ustawodawcę zadań, których realizacja została przyznana państwu na wyłączność. Te zmiany były powodem podzielenia dochodów publicznych tak, aby umożliwić finansowanie zadań, jakie zostały przyznane j.s.t. Jednostki podziału terytorialnego działały wówczas zgodnie z założeniem, że dochody przyznane im w przepisach nie są wystarczające do wykonania zadań samorządu, dlatego musiały korzystać z zasobów budżetu państwa oraz innych publicznych środków. Uporządkowanie sytuacji prawnej gospodarki finansowej j.s.t. nastąpiło po uchwaleniu ustawy o samorządzie terytorialnym. Za sprawą zmiany Konstytucji z 19 marca 1990 r. wyodrębniona została gmina jako nowy podmiot publiczny wyposażony w osobowość prawną.

Z perspektywy funkcjonowania finansów j.s.t. ważnym krokiem było wydzielenie powiatów oraz województw w 1998 roku. Obowiązująca wówczas ustawa o dochodach j.s.t. ${ }^{15}$ określała źródła dochodów tych jednostek oraz zasady przyznawania, przekazywania subwencji oraz dotacji, ponadto podzielono dochody samorządu na obligatoryjne i fakultatywne.

Obecnie dochody j.s.t. co do zasady stanowią pewien zamknięty zbiór, ich miejsce w porządku prawnym wynika z kilku aktów prawnych o różnym stopniu szczegółowości. Obowiązująca ustawa o dochodach j.s.t. nie jest jedynym aktem, który wskazuje na katalog źródeł dochodów j.s.t., co w praktyce może powodować pewne rozbieżności na płaszczyźnie podziału dochodów samorządu terytorialnego.

Klasyfikacje dochodów mogą być dokonywane przy uwzględnieniu zróżnicowanych kryteriów, niektóre z nich są spójne i uwzględniają ład pojęciowy, jednak są i takie odbiegające od tych założeń. Konstytucja RP uwzględnia regulacje dotyczące dochodów j.s.t., które są rozproszone, uregulowane w różnych częściach ustawy zasadniczej. Przepisy te wyznaczają podstawowe zasady funkcjonowania samorządu terytorialnego, które oparte są na gwarancji zapewnienia zdolności wykonywania zadań publicznych w imieniu własnym i na własną odpowiedzialność.

15 Ustawa o dochodach jednostek samorządu terytorialnego w latach 1999-2000 (Dz.U. z 1998 r. Nr 150, poz. 983 ze zm.) obowiązująca do 2003 r. 
Decentralizacja władzy publicznej jest procesem dynamicznym, pozwalającym na coraz szersze przyznawanie kompetencji jednostkom, które znajdują się najbliżej danej społeczności lokalnej ${ }^{16}$. Należy jednak zaznaczyć, że aby proces decentralizacji nie był fikcją, wraz z przekazywaniem kompetencji w aspekcie materialnoprawnym oraz proceduralnym powiązana musi być decentralizacja finansowa. Zapewnia ona możliwość realizacji przyznanych jednostce zadań, jakie może ona wykonywać z wykorzystaniem środków finansowych, którymi samodzielnie dysponuje w granicach obowiązujących przepisów. Każdy z obowiązujących aktów prawnych - zarówno EKSL, ustawa zasadnicza, jak i ustawy zwykłe - podkreśla znaczenie rozwiązań prawnych, które zapewnią adekwatność środków w zakresie ich wysokości oraz struktury dochodów do zadań, jakie dana jednostka ma realizować ${ }^{17}$.

\section{Realizacja zadań jednostek samorządu terytorialnego w kontekście swobody dysponowania środkami publicznymi}

Reglamentacja prawna gospodarki finansowej jednostek sektora finansów publicznych może mieć kształt wspólnych zasad ogólnych finansów lub formę odrębnych zasad szczegółowych, które dotyczą zarówno gromadzenia, jak i wydatkowania środków publicznych. Współcześnie zasady gospodarki finansowej mają przede wszystkim charakter normatywny, co nie wyklucza obowiązywania pewnych zasad ukształtowanych na podstawie praktyki działania organów administracji publicznej czy sądów.

Na gruncie Konstytucji RP samorząd terytorialny jest formą podziału zadań, wydatków i dochodów publicznych pomiędzy państwo a gminy, powiaty i województwa. Główny problem o charakterze organizacyjnym dotyczy sposobu prowadzenia tego podziału tak, aby zagwarantować wła-

16 E. Stupienko, Dochody zwiqzane z realizacja zadań zleconych jako publicznoprawne, niepodatkowe należności budżetowe, „Finanse Komunalne” 2018, nr 6, s. 10-14.

17 R. Kowalczyk, Finansowo-prawne instrumenty kształtowania niepodatkowych dochodów własnych gmin o charakterze o charakterze publicznoprawnym, Wrocław 2019, s. $17-23$. 
ściwy poziom decentralizacji w kwestii zadań oraz dochodów i wydatków publicznych. W związku z powyższym można wskazać na różne modele finansowania samorządu terytorialnego, które cechuje odmienny poziom samodzielności finansowej ${ }^{18}$.

Dochody publiczne, którymi dysponują jednostki samorządu terytorialnego, powinny być dostosowane do zadań, jakie są nakładane na te podmioty. W przypadku zlecenia gminie nowych zadań niezbędne środki mogą pochodzić ze zwiększonych dochodów własnych lub subwencji ${ }^{19}$. Ustawa o samorządzie powiatowym wskazuje, że w razie przekazania danej jednostce nowych zadań należy zapewnić jej należne środki w postaci zwiększonego finansowania ${ }^{20}$. Na poziomie województwa w razie przekazania danej jednostce nowych zadań należy zapewnić jej konieczne środki finansowe poprzez zwiększenie dochodów własnych ${ }^{21}$.

Ustawa o dochodach jednostek samorządu terytorialnego określa obligatoryjne źródła dochodów gmin, powiatów oraz województw, umożliwiając pozyskiwanie przez j.s.t, dodatkowych środków w postaci fakultatywnych źródeł dochodów jako środków pochodzących ze źródeł zagranicznych niepodlegające zwrotowi, środków pochodzących z budżetu Unii Europejskiej oraz innych środków określonych w odrębnych przepi$\operatorname{sach}^{22}$. Do najważniejszych dochodów j.s.t. zaliczono: dochody własne, subwencje ogólne oraz dotacje celowe z budżetu państwa ${ }^{23}$.

Do obligatoryjnych źródeł dochodów własnych gmin, powiatów i województw należą przede wszystkim dochody podatkowe, w przypadku gmin: wpływy z podatków i opłat samorządowych, tj. od nieruchomości, rolnego, leśnego, od środków transportowych, od działalności gospodarczej osób fizycznych, opłacanego w formie karty podatkowej, od spadków i darowizn, od czynności cywilnoprawnych; wpływy z opłat:

18 M. Bogucka-Felczak, Konstytucyjne determinanty funkcjonowania mechanizmów korekcyjno-wyrównawczych w systemie dochodów jednostek samorzq̨u terytorialnego, Warszawa 2017, s. 33-35.

19 Por. art. 7 ust. 3 u.s.g.

20 Por. art. 56 ust. 3 u.s.p.

21 Por. art. 67 ust. 3 u.s.w.

22 Por. art. 3 ust. 3 u.d.j.s.t.

23 Por. art. 3 ust. 1 u.d.j.s.t. 
skarbowej, eksploatacyjnej, uzdrowiskowej, innych stanowiących dochody gminy.

W ustawie wskazano także źródła pozyskiwania środków finansowych o charakterze niepodatkowym, do których można zaliczyć m.in.: dochody generowane przez jednostki budżetowe, środki wpłacane przez samorządowe zakłady budżetowe, spadki, zapisy oraz darowizny, których beneficjentami są j.s.t., wpływy z kar pieniężnych i grzywien regulowane odrębnymi przepisami, odsetki od pożyczek, które gminy, powiaty i województwa udzielają. Na obligatoryjne podatkowe dochody własne j.s.t. składają się ponadto udziały w podatkach dochodowych w postaci udziału we wpływach z podatku dochodowego od osób fizycznych, od podatników tego podatku zamieszkałych na obszarze j.s.t., oraz we wpływach z podatku dochodowego od osób prawnych, od podatników tego podatku posiadających siedzibę na obszarze danej j.s.t ${ }^{24}$.

Model zarządzania państwem na płaszczyźnie finansowej powinien być ukierunkowany na decentralizację środków w j.s.t. Aby urzeczywistnić to rozwiązanie, należy kierować się zasadami wynikającymi z teorii finansów publicznych, do których zaliczymy konieczność instrumentalnego dostosowania środków publicznych do zadań rzeczowych, wykształcenie sprawnie działającego systemu zasilania finansowego oraz alokacji środków, a także zachowanie władztwa podatkowego na poziomie centralnym, w którym skala obciążeń podatkowych powinna być regulowana centralnie. Istotne, aby granice dozwolonego zadłużenia j.s.t. były precyzyjnie określone w ustawach. Dla wdrożenia wymienionych rozwiązań i ich prawidłowego funkcjonowania ważne jest, aby zachować istniejące źródła finansowania, a także zakres samodzielności j.s.t. co najmniej na obecnym poziomie, przy jednoczesnym wzmacnianiu finansowych podstaw działalności tych jednostek. Kluczowa jest stabilność podstawowych podatków, które służą zasileniu j.s.t., a ewentualne zmiany muszą być skorelowane ze zmianami na gruncie podatków lokalnych. Ponadto w celu dostosowania reformy finansów publicznych w zakresie decentralizacji

24 W gminie art. 4 ust. 2 i 3 u.d.j.s.t., powiecie art. 5 ust. 2 i 3 u.d.j.s.t., województwie art. 6 ust. 2 i 3 u.d.j.s.t. 
należy uwzględnić nie tylko aktualne, ale również przyszłe możliwości finansowe jednostek ${ }^{25}$.

Na poziomie powiatów i województw zasadne wydaje się zwiększenie znaczenia dochodów podatkowych poprzez wprowadzenie udziałów pośrednich szczebli samorządu terytorialnego np. w podatku od nieruchomości. Natomiast zmiany w podatkach centralnych powinny polegać na wprowadzeniu dla j.s.t. dodatków do podatków dochodowych ${ }^{26}$.

Poza podatkami ważnym źródłem finansowania j.s.t. są transfery środków z budżetu państwa do budżetów gmin, powiatów i województw, a także pomiędzy budżetami samorządowymi. Transfery te są podstawowym źródłem dochodów, zwłaszcza pośrednich szczebli samorządu terytorialnego. W związku z tym prawidłowo działający system redystrybucji środków publicznych pomiędzy poszczególnymi budżetami ma fundamentalne znaczenie. Opracowanie i przyjęcie odpowiedniego modelu dotowania gmin, powiatów i województw jest jednak zadaniem znacznie trudniejszym niż prezentacja koncepcji repartycji dochodów podatkowych pomiędzy państwo i samorząd terytorialny. Wynika to z faktu, iż w przypadku systemu dotowania istnieje znacznie większa liczba możliwych do przyjęcia modeli rozwiązań ${ }^{27}$.

\section{Znaczenie samodzielności oraz stabilności finansowej j.s.t.}

Pojęciu samodzielności finansowej samorządu terytorialnego można przypisać różne znaczenia. Zawsze jednak łączy się je z uprawnieniami (swobodą) j.s.t. do kształtowania wysokości dochodów, wydatkowania środków oraz prowadzenia gospodarki finansowej. Tak samo pojęcie to rozumie Trybunał Konstytucyjny ${ }^{28}$. Samodzielność finansowa j.s.t. zależy

25 K. Surówka, M. Winiarz, Kierunki zmian ustawy o dochodach jednostek samorzqdu terytorialnego [w:] P. Kopyciński (red.), Sprawne Państwo, Propozycje zmian w funkcjonowaniu jednostek samorzq̨du terytorialnego w Polsce, Kraków 2017, s. 9-12.

26 B. Pahl, Podatki i opłaty lokalne. Teoria i praktyka, Warszawa 2017, s. 23-26.

27 Por. K. Surówka, Samodzielność finansowa samorzq̨du terytorialnego w Polsce, Warszawa 2016, s. 76.

28 Wyrok TK z dnia 16 marca 1999 r., K 35/98, OTK 1999, nr 3, poz. 37. 
od struktury dochodów j.s.t. Stopień samodzielności finansowej tych jednostek jest tym większy, im większy jest udział dochodów własnych w strukturze dochodów samorządu terytorialnego, oraz tym jest mniejszy, im większy jest udział dotacji celowych w finansowaniu zadań samorządu. Trybunał Konstytucyjny uznał, że istotą samodzielności finansowej jest zapewnienie j.s.t. środków umożliwiających wywiązanie się tych podmiotów z zadań, jakie zostały im przypisane, gwarantując jednocześnie swobodę decyzyjną w zakresie sposobu wydatkowania środków oraz tworząc właściwe fundamenty formalne i proceduralne ${ }^{29}$. Samodzielność ta nie ma charakteru absolutnego, podlega jednak ochronie prawnej ${ }^{30}$.

Dla prawidłowego funkcjonowania gospodarki finansowej j.s.t. potrzebna jest stabilność finansowa, która gwarantuje pewność, przewidywalność, równowagę i bezpieczeństwo sytemu gromadzenia i wydatkowania środków publicznych. W takim stanie system finansowy może realizować swoje funkcje w sposób efektywny i ciągły, jednak jako warunek sine qua non wymienia się znaczenie zrównoważonego rozwoju w perspektywie długoterminowej ${ }^{31}$. Ideą zrównoważonego rozwoju jest rozwój, w którym realizowane są potrzeby społeczności, bez ograniczenia szans następnych pokoleń na zaspokojenie tych samych potrzeb.

Geneza pojęcia zrównoważonego rozwoju ma swoje fundamenty na gruncie leśnictwa. Oznaczało ono taki sposób gospodarowania lasem, w którym wycina się tylko tyle drzew, ile może w to miejsce urosnąć, tak by las nigdy nie został zlikwidowany i jednocześnie mógł samodzielnie się regenerować ${ }^{32}$. Zaprezentowana definicja ukazuje wąskie ujęcie zagadnienia, które znajduje odniesienie także na innych płaszczyznach.

\footnotetext{
Wyrok TK z dnia 24 marca 1998 r., K 40/97, OTK 1998, nr 2, poz. 12.

Por. orzeczenia TK z dnia 4 października 1995 r., K 8/95, OTK 1995, nr 2, poz. 8; z dnia 23 października 1996 r., K 1/96, OTK 1996, nr 5, poz. 38; z dnia 15 grudnia 1997 r., K 13/97, OTK 1997, nr 5-6, poz. 69, oraz z dnia 3 listopada 1998 r., K 12/98, OTK 1998, nr 6, poz. 98.

31 Raport o stabilności systemu finansowego, Narodowy Bank Polski, Warszawa 2016, https://www.nbp.pl/systemfinansowy/rsf122016.pdf , s. 9-10, (dostęp: 3.01 .2020 r.).

32 Światowa Komisja ds. Środowiska i Rozwoju (WCED), Raport „Nasza wspólna przyszłość", http://www.europarl.europa.eu/meetdocs/2009_2014/documents/envi/dt/ 893/893910/893910pl.pdf, (dostęp: 3.01.2020 r.).
} 
W związku z powyższym, aby określić rozwój jako trwały i zrównoważony, należy wykazać, że chodzi o takie wykorzystywanie ograniczonych zasobów o charakterze przyrodniczym czy kulturalnym, których nie można odnowić lub ich zdolność do samoodtworzenia jest ograniczona. Prawidłowe rozumienie istoty rozwoju to postęp obejmujący równocześnie kilka płaszczyzn: dobrobyt gospodarczy, społeczną stabilność oraz równowagę środowiska naturalnego, dlatego aby uzyskać trwałe zmiany, należy uwzględnić wszystkie jego aspekty - zarówno ten społeczny, jak i środowiskowy oraz gospodarczy ${ }^{33}$.

Stabilność finansowa związana jest ze zdolnością jednostki samorządu terytorialnego do finansowania zadań własnych oraz zleconych w wymiarze dochodowym. W znaczeniu usługowym to świadczenie usług publicznych w sposób ciągły i efektywny, a w ujęciu zadłużeniowym oznacza regulowanie zobowiązań finansowych ${ }^{34}$.

Doktryna łączy pojęcie stabilności finansowej z możliwością zapewnienia przez władze samorządowe realizacji usług publicznych oraz utworzenia warunków do rozwoju społeczno-gospodarczego ${ }^{35}$. Kluczowym elementem stabilności finansowej jest system finansowania j.s.t. realizowany w oparciu o zasadę wydajności fiskalnej, rozumianej jako możliwość efektywnego realizowania funkcji samorządu, oraz zasadę stałości, czyli zapewnienia pewności prawnej dochodów j.s.t. ${ }^{36}$

Gospodarka finansowa gmin, powiatów i województwa działa w oparciu o uchwałę budżetową, która składa się z budżetu oraz załączników. W budżecie jednostki oznaczone zostają jej dochody i wydatki, przychody, rozchody oraz wynik finansowy stanowiący nadwyżkę lub

33 P. Magnuszewski, Zrównoważony rozwój jako koncepcja systemowa [w:] T. Bergier, J. Kronenberg (red.), Wyzwania zrównoważonego rozwoju w Polsce, Kraków 2010, s. 44.

34 M. Poniatowicz, Stabilność finansowa jednostek samorzqdu terytorialnego $w$ aspekcie nowej perspektywy finansowej Unii Europejskiej i zmian w systemie dochodów samorzqdowych, „Ekonomiczne Problemy Usług” 2016, nr 125, s. 8-10.

35 K. Wójtowicz, Podział zadań publicznych między państwo a samorzq̨ a problem zapewnienia stabilności fiskalnej, „Nierówności Społeczne a Wzrost Gospodarczy” 2014, nr 40, s. 305.

36 K. Wójtowicz, Udział w podatkach państwowych a problem stabilności fiskalnej jednostek samorzqdu terytorialnego w Polsce, „Annales Universitatis Mariae Curie-Skłodowska” 2014, nr 2, s. 137. 
deficyt. Budżet uchwalany jest na rok budżetowy, który tak samo jak rok kalendarzowy rozpoczyna się 1 stycznia, a kończy wraz z ostatnim dniem roku, czyli 31 grudnia. Długoterminowa gospodarka finansowa w j.s.t. prowadzona jest na podstawie opracowanej wieloletniej prognozy finansowej, której horyzont czasowy obejmuje okres danego roku budżetowego i przynajmniej trzech kolejnych lat. Wieloletnie planowanie umożliwia przygotowanie przez Ministra Finansów strategii zarządzania długiem Skarbu Państwa oraz wpływu na państwowy dług publiczny. W prognozowaniu jednostka ujmuje wszelkie przedsięwzięcia, programy, projekty, zadania inwestycje, uwzględniając te finansowane $\mathrm{z}$ wykorzystaniem środków pochodzących z Unii Europejskiej oraz umów o partnerstwie publiczno-prywatnym ${ }^{37}$.

Gospodarka finansowa stanowi ważną płaszczyznę dla decyzji podejmowanych przez samorządy lokalne w zakresie prowadzonej przez nie działalności. W związku z tym istotne jest racjonalne gospodarowanie ograniczonymi zasobami finansowymi. Dysponenci środków powinni natomiast skoncentrować się na poszukiwaniu najkorzystniejszych sposobów finansowania zadań oraz pozyskiwaniu środków także z udziałem źródeł zewnętrznych czy zagranicznych.

Gospodarkę finansową j.s.t. można postrzegać na kilku płaszczyznach:

1. poprzez wskazanie jej słabych i mocnych stron dzięki analizie funkcjonalnej;

2. oznaczając obszary, w których jedynie interdyscyplinarne zaangażowanie pozwoli na stworzenie nowej metodologii rozwiązania danego problemu i opracowania schematu działań realizowanych w interesie społeczności lokalnej;

3. poprzez ukazanie możliwości w kontekście zmiany struktury gospodarki finansowej samorządu, zasad funkcjonowania oraz metod, któ-

37 Por. art. 211 ust. 4 oraz 214 u.f.p. w załącznikach do uchwały budżetowej zamieszcza się: zestawienie planowanych kwot dotacji udzielanych z budżetu j.s.t., plan dochodów rachunku dochodów samorządowych jednostek budżetowych, plany przychodów i kosztów samorządowych zakładów budżetowych. 
re przyczynią się do wzrostu efektywności dysponowania środkami publicznymi ${ }^{38}$.

W celu uzyskania pełnego obrazu sposobu działania gospodarki finansowej w jednostkach samorządu terytorialnego należy przeanalizować jej prawne i organizacyjne podstawy, kryteria dysponowania środkami publicznymi, zasady rachunkowości oraz sprawozdawczości budżetowej, sposób prowadzenia kontroli i nadzoru finansowego oraz kompetencje i kwalifikacje pracowników jednostek. Wymienione obszary stanowią odzwierciedlenie wielu czynników, jakie powinny zostać wykorzystane podczas oceny funkcjonowania gospodarki finansowej jednostki.

\section{Zasada adekwatności gospodarowania środkami publicznymi na gruncie przepisów krajowych oraz orzecznictwa Trybunału Konstytucyjnego}

Wszystkie poziomy w strukturze władz lokalnych dysponują możliwością kształtowania określonych dochodów oraz ustalania kierunków dokonywania wydatków budżetowych, co stanowi istotny wyznacznik samorządności w kontekście prowadzonej gospodarki finansowej. Kluczowe w tym względzie jest zapewnienie powiązania źródeł dochodów z działalnością jednostek, które obejmują teren działania władz samorządowych, gwarantując rozwój danego obszaru, realizacje zasad adekwatności oraz elastyczności, pozwalając na zwiększenie dochodów stosownie do rozszerzonych zadań i wydatków.

Źródła dochodów pomiędzy jednostkami samorządowymi powinny być rozmieszczone równomiernie, co uwidacznia się w formach subwencji wyrównawczych, różnicowaniu źródeł dochodów, z zapewnieniem stabilności i pewności źródeł poboru tych dochodów w długim okresie

38 Por. A. Szewczuk, Aktywny system kreowania zasobów finansowych na poziomie jednostek samorzqdu terytorialnego warunkiem podnoszenia konkurencyjności regionów [w:] L. Pawłowicz, R. Wierzba (red.), Finanse publiczne wobec procesów globalizacji, Gdańsk-Jurata 2003, s. 316-323. 
tak, aby zaspokoić potrzeby finansowe samorządu i pozwolić na jego rozwój.

Określenie poziomu decentralizacji finansowej jednostki umożliwia zasada adekwatności środków do wyznaczonych zadań, rozumiana w ujęciu statycznym i dynamicznym. Należy podkreślić, że na gruncie zasady adekwatności priorytetem jest właściwe ukształtowanie źródeł dochodów samorządowych w sposób pozwalający na zagwarantowanie pełnego oraz prawidłowego finansowania inwestycji ujętych w katalogu zadań danej jednostki ${ }^{39}$. Zasada ta w ujęciu statycznym stanowi podstawowy standard samorządowy wyrażony w przepisach prawa. Art. 167 ust. 1 Konstytucji RP stanowi, że j.s.t. powinny mieć zagwarantowany odpowiedni udział w systemie dochodów publicznych. Odpowiedniość oznacza w tym kontekście stan, który pozwala tym jednostkom właściwe wykonywać powierzone im zadania ${ }^{40}$. Konstytucyjny zapis wskazuje na potrzebę zagwarantowania j.s.t. środków w wysokości, która pozwoli na staranną realizację zadań, jakie przypisane są poszczególnym jednostkom samorządu terytorialnego co najmniej w minimalnym stopniu ${ }^{41}$.

Europejska Karta Samorządu Lokalnego zakłada kreowanie przez władze państw członkowskich sprzyjających warunków do realizowania zadań statutowych j.s.t. Uwzględniając doświadczenia funkcjonowania samorządów, wydaje się zasadne twierdzenie o potrzebie zapewnienia samorządom wystarczających zasobów finansowych. W rzeczywistości plany rozwojowe j.s.t. są uzależnione od dostępnych źródeł zasilenia finansowego. Pomimo chęci zrealizowania oczekiwań społeczności lokalnych najczęściej jest to niemożliwe ze względu na brak wystarczających zasobów finansowych i organizacyjnych. Jednostki samorządu terytorialnego jako wskazówkę mogą wykorzystywać zapisy EKSL, zgodnie z którymi społeczności lokalne winny dysponować odpowiednimi środ-

39 Pogląd przedstawicieli doktryny, m.in. E. Kornberger-Sokołowskiej oraz E. Chojny-Duch.

40 Por. wyrok TK z dnia 28 czerwca 2001 r., U 8/00, OTK Seria A 2001 nr 3, poz. 28.

41 Z. Niewiadomski, Samorzq̨d terytorialny w Konstytucji RP, „Samorząd Terytorialny” 2002, nr 3, s. 17. 
kami finansowymi niezbędnymi do prawidłowego wykonania powierzonych im zadań ${ }^{42}$.

Wymaga podkreślenia, że samodzielność j.s.t. w kontekście sposobu prowadzenia gospodarki finansowej jest mocno skorelowana $\mathrm{z}$ ich autonomią w pozyskiwaniu i swobodnym wydatkowaniu środków. Trudno o „złotą regułę w aspekcie podziału środków budżetowych”, nie oznacza to jednak, że jest to zadanie niemożliwe do zrealizowania. Zapewnienie ochrony społecznościom lokalnym wymaga wdrożenia procedur wyrównawczych lub działań równoważących, których celem jest niwelowanie skutków nierównego alokowania prognozowanych źródeł dochodów, a także wydatków, jakie te społeczności ponoszą ${ }^{43}$. Realizację postanowień zawartych w EKSL umożliwiają udzielane subwencje ogólne czy dotacje celowe. Środki te w przeważającej części są przyznawane określonym podmiotom, dlatego brak pełnej swobody w sposobie podziału tych środków przez władze samorządowe. Poprzez swoją konstrukcję oraz narzędzia, w jakie jest wyposażony, mechanizm podziału dochodów między poszczególne sektory (rządowy i samorządowy) powinien skutecznie oddziaływać na efektywność zarządzania zasobami publicznymi ${ }^{44}$.

Należy wskazać, że na skutek decentralizacji finansowej zasada adekwatności zyskuje poza płaszczyzną statyczną także wymiar dynamiczny. Stały wzrost zakresu powinności samorządowych wymaga odpowiednich zmian w systemie zasilania tych podmiotów. W myśl postanowień Konstytucji RP wprowadzenie zmian w obszarze zadań oraz kompetencji j.s.t. powinno być realizowane wraz ze zmianami w podziale dochodów publicznych ${ }^{45}$. Urzeczywistnienie tego postulatu możliwe jest głównie poprzez system gwarancji oraz roszczeń o wyposażenie w środki finansowe, które będą wystarczające dla realizowanych zadań, a także zabezpieczeń, które umożliwią określenie prawidłowego poziomu oraz struktury tych dochodów.

\footnotetext{
Art. 9 ust. 1 EKSL.

43 Art. 9 ust. 5 EKSL.

44 Z. Ofiarski, Standard z art. 9 ust. 3 EKSL jako wzorzec kontroli na przykładzie wybranych orzeczeń Trybunału Konstytucyjnego [w:] M. Ofiarska (red.), EKSL a prawo samorzqdu terytorialnego, Szczecin 2015, s. 70-72.

45 Art. 167 ust. 4 Konstytucji RP.
} 
Realizacja postulatów zasady adekwatności w procesach decentralizacji finansowej uwidacznia się w metodach wyznaczania wielkości środków finansowych wyodrębnianych z budżetu państwa oraz przekazywanych j.s.t. Te procesy określają rolę systemu transferów wyrównawczych, do którego zaliczyć należy subwencje ogólne oraz dotacje celowe w toku finansowania inwestycji na poziomie samorządowym, przy jednoczesnym uwidocznieniu poziomu samodzielności dochodowej j.s.t.

Subwencja ogólna pochodząca z budżetu centralnego jest egzemplifikacją decentralizacji finansowej, ponieważ jednocześnie z transferem środków zachodzi przeniesienie uprawnień do podejmowania decyzji o sposobie ich wydatkowania, wówczas traktowane są one jako względnie neutralne dla samodzielności jednostki ${ }^{46}$.

Jednostki samorządu terytorialnego z powodu niewystarczających zasobów finansowych nie mają szans urzeczywistniać w pełni swoich strategii rozwojowych. W związku z tym stworzenie warunków, w których poziom rozwoju regionalnego byłby zgodny z oczekiwaniami społeczności lokalnych, jest utrudnione ${ }^{47}$. Samorządy lokalne na poszczególnych poziomach nie dysponują programami wzajemnej współpracy. Warto podkreślić, że demokratyzacja życia na poziomie społeczności lokalnych sprawia, iż władze samorządowe powinny uwzględniać zdanie tych podmiotów w odniesieniu do realizowanych inwestycji, w zakresie podziału środków publicznych.

Uwzględniając potrzeby jednostek samorządu terytorialnego, skuteczna realizacja zadań publicznych wymaga zespołowych działań. Przeobrażenia gospodarki finansowej w j.s.t. powinny być skupione na następujących aspektach:

- głównym wyzwaniem jest konieczność praktycznej realizacji określonej w Konstytucji RP zasady adekwatności dochodów j.s.t. do zadań,

46 Por. M. Dworakowska, Dochody budżetowe jednostek samorzqdu terytorialnego z perspektywy absorpcji funduszy unijnych, „Optimum. Economic Studies” 2018, nr 3, s. 53-54.

47 Por. H. Janowska, Strategie finansowania gminnych inwestycji infrastrukturalnych w Polsce, Szczecin 2002, s. 73-114. 
jakie są im przydzielone na poziomie gmin, powiatów i województw jako zadania własne i zlecone;

- środki stanowiące wpływy z podatku dochodowego od osób fizycznych oraz od osób prawnych powinny wyodrębniać część państwową oraz samorządowej;

- $\quad$ ważne jest poszerzenie bazy podatkowej dochodów j.s.t,, a w szczególności znaczny wzrost udziału podatków w dochodach samorządu w gminach, powiatach i województwach;

- j.s.t. powinny przejąć - jako dochody własne - dochody instytucji centralnych, które wykonują lub finansują zadania o charakterze lokalnym;

- $\quad$ właściwego rozmieszczenia źródeł dochodów pomiędzy jednostkami samorządowymi w państwie, w zakresie subwencji o charakterze wyrównawczym oraz zróżnicowaniu źródeł dochodów, w związku z potrzebą czerpania tych środków w różnych formach, rozmiarach i o różnym znaczeniu fiskalnym, co wyraża się w wielości tych źródeł w polskim prawie;

- zagwarantowania stabilność i pewność źródeł poboru dochodów w stosunkowo długim okresie oraz ich wydajność, które pozwoliłyby na zrealizowanie zadań samorządowych, utrzymanie dostępnej infrastruktury, a ponadto jej rozwój.

\section{Wnioski}

Nie tracą na aktualności postulaty wprowadzenia zmian na płaszczyźnie dochodów j.s.t. prowadzące do zwiększenia udziału dochodów własnych z jednoczesnym pogłębieniem skuteczności działania mechanizmów wyrównawczych w systemie dochodów samorządu terytorialnego. Jako wniosek de lege lata należy przyjąć, że rozwój gospodarki finansowej w sektorze samorządowym jest procesem złożonym i długoterminowym, który wymaga zaangażowania wszystkich zainteresowanych osiągnięciem przez społeczności lokalne standardów jakościowych, które przyczynią się do zrównoważonego rozwoju. 
Jako postulat de lege ferenda można wskazać, że istnieją rzeczywiste możliwości zmiany obecnej struktury finansów samorządu terytorialnego i wdrożenia programów, które spowodują efektywniejsze dysponowanie środkami publicznymi (w tym samorządowymi). Wśród wyzwań, które stoją przed samorządem, należy uwzględnić stały wzrost udziału dochodów własnych w strukturze zasobów finansowych - im wyższy udział dochodów własnych w finansowaniu wydatków, tym większa samodzielność i lepsze możliwości, aby realizować programy rozwojowe.

Wiele gmin, powiatów i województw jest zadłużonych, władze samorządowe dostrzegają ten problem, którego rozwiązaniem może być korzystanie $\mathrm{z}$ pozabudżetowych źródeł finansowania $\mathrm{w}$ postaci m.in. umów o partnerstwie publiczno-prywatnym ${ }^{48}$. Zasadnym wydaje się sformułowanie postulatów dotyczących konieczności ujednolicenia regulacji na płaszczyźnie wymiaru i poboru dochodów j.s.t., a przede wszystkim zapewnienie jednolitego zakresu pojęciowego. W związku z tym zasadne byłoby wprowadzenie zmian w ustawie o finansach publicznych, Ordynacji podatkowej oraz ustawie o dochodach jednostek samorządu terytorialnego, poprzez utworzenie jednej spójnej kategorii prawnej dla określenia m.in. niepodatkowych dochodów budżetu o charakterze publicznoprawnym. Takie rozwiązanie zwiększyłoby przejrzystość regulacji oraz wyeliminowało występujące rozbieżności w zakresie wykładni.

Finanse j.s.t., szczególnie dochody jednostek, oddziałują na zdolność tych podmiotów do realizowania zadań publicznych. Wśród wszystkich dochodów szczególne miejsce zajmują dochody własne, które przyczyniają się do zapewnienia lepszych możliwości sfinansowania zaplanowanych przedsięwzięć. Dochody własne są ograniczone, dlatego konieczne jest poszukiwanie innych sposobów finansowania, z uwzględnieniem źródeł zagranicznych, które mogą przyczynić się do przyspieszenia rozwoju danej jednostki. Należy zaznaczyć, że na przestrzeni ostatnich stu lat sposób prowadzenia gospodarki finansowej w jednostkach samorządu terytorialnego ulegał przemianom, w dynamicznym ujęciu można obserwować

48 A. Szewczuk, Dylematy gospodarki finansowej w polskim sektorze samorzqdowym na tle akcesji do Unii Europejskiej, „Acta Universitatis Lodziensis. Folia Oeconomica” 2006, nr 197, s. 351. 
działania zmierzające zagwarantowaniu j.s.t. dochodów adekwatnych do powierzanych im zadań.

\section{Bibliografia:}

Bogucka-Felczak M., Konstytucyjne determinanty funkcjonowania mechanizmów korekcyjno-wyrównawczych w systemie dochodów jednostek samorzq̨du terytorialnego, Wydawnictwo Poltext, Warszawa 2017.

Dworakowska M., Dochody budżetowe jednostek samorzqdu terytorialnego z perspektywy absorpcji funduszy unijnych, „Optimum. Economic Studies” 2018, nr 3, s. 51-62.

Dylewski M., Filipiak B., Gorzałczyńska-Koczkodaj M., Podstawy analizy finansowej w jednostkach samorzqdu terytorialnego, Wydawnictwo Naukowe Uniwersytetu Szczecińskiego, Szczecin 2003.

Janowska H., Strategie finansowania gminnych inwestycji infrastrukturalnych w Polsce, Wydawnictwo Naukowe Uniwersytetu Szczecińskiego, Szczecin 2002.

Kowalczyk R., Finansowo-prawne instrumenty kształtowania niepodatkowych dochodów własnych gmin o charakterze o charakterze publicznoprawnym, EWydawnictwo. Prawnicza i Ekonomiczna Biblioteka Cyfrowa. Wydział Prawa, Administracji i Ekonomii Uniwersytetu Wrocławskiego, Wrocław 2019.

Magnuszewski P., Zrównoważony rozwój jako koncepcja systemowa [w:] T. Bergier, J. Kronenberg (red.), Wyzwania zrównoważonego rozwoju w Polsce, Fundacja Sędzimira, Kraków 2010.

Niewiadomski Z., Samorzq̨d terytorialny w Konstytucji RP, „Samorząd Terytorialny” 2002, nr 3, s. 3-30.

Ofiarski Z., Standard z art. 9 ust. 3 EKSL jako wzorzec kontroli na przykładzie wybranych orzeczeń Trybunału Konstytucyjnego [w:] M. Ofiarska (red.), Europejska Karta Samorzqdu Lokalnego a prawo samorzq̨du terytorialnego, Uniwersytet Szczeciński. Wydział Prawa i Administracji, Szczecin 2015.

Pahl B., Podatki i opłaty lokalne. Teoria i praktyka, Wolters Kluwer, Warszawa 2017.

Poniatowicz M., Stabilność finansowa jednostek samorzqdu terytorialnego w aspekcie nowej perspektywy finansowej Unii Europejskiej i zmian w systemie dochodów samorzq̨dowych, „Ekonomiczne Problemy Usług” 2016, nr 125, s. 7-23. 
Stupienko E., Dochody zwiqzzane z realizacjq zadań zleconych jako publicznoprawne, niepodatkowe należności budżetowe, „Finanse Komunalne” 2018, nr 6, s. 24-31.

Surówka K., Samodzielność finansowa samorzq̨u terytorialnego w Polsce, Polskie Wydawnictwo Ekonomiczne, Warszawa 2016.

Surówka K., Winiarz M., Kierunki zmian ustawy o dochodach jednostek samorzq̨du terytorialnego [w:] P. Kopyciński (red.), Sprawne Państwo, Propozycje zmian $w$ funkcjonowaniu jednostek samorzqdu terytorialnego w Polsce, Uniwersytet Ekonomiczny w Krakowie Małopolska Szkoła Administracji Publicznej, Kraków 2017.

Szczechowicz H., Wykonywanie zadań publicznych w jednostkach samorzq̨du terytorialnego, „Zeszyty Naukowe Państwowej Wyższej Szkoły Zawodowej we Włocławku. Zbliżenia Cywilizacyjne” 2015, nr 11, s. 255-287.

Szewczuk A., Dylematy gospodarki finansowej w polskim sektorze samorzqdowym na tle akcesji do Unii Europejskiej, „Acta Universitatis Lodziensis. Folia Oeconomica” 2006, nr 197, s. 349-359.

Szewczuk A., Aktywny system kreowania zasobów finansowych na poziomie jednostek samorzqdu terytorialnego warunkiem podnoszenia konkurencyjności regionów [w:] L. Pawłowicz, R. Wierzba (red.), Finanse publiczne wobec procesów globalizacji, Uniwersytet Gdański i Gdańska Akademia Bankowa, Gdańsk-Jurata 2003.

Szyszko I., Szczepański J. (red.), Finanse przedsiębiorstwa, Polskie Wydawnictwo Ekonomiczne, Warszawa 2003.

Wojciechowski E., Gospodarka samorzqdu terytorialnego, Difin, Warszawa 2012.

Wójtowicz K., Podział zadań publicznych między państwo a samorzq̨d a problem zapewnienia stabilności fiskalnej, „Nierówności Społeczne a Wzrost Gospodarczy” 2014, nr 40, s. 305-312.

Wójtowicz K., Udział w podatkach państwowych a problem stabilności fiskalnej jednostek samorzqdu terytorialnego w Polsce, „Annales Universitatis Mariae Curie-Skłodowska”, 2014, nr 2, s. 135-143. 